\title{
Do state traditions matter? Comparing deliberative governance initiatives for climate change adaptation in Dutch corporatism and British pluralism
}

\author{
M. J. Vink, D. Benson, D. Boezeman, H. Cook, A. Dewulf and C. Termeer
}

\begin{abstract}
In the emerging field of climate adaptation, deliberative governance initiatives are proposed to yield better adaptation strategies. However, introducing these network-centred deliberations between public and private players may contrast with traditions of interest intermediation between state and society. This paper shows how state traditions affect newly set up deliberative governance initiatives. Because of the similarities in geographical characteristics and the differences in state tradition we choose qualitative case studies in Dutch and British water management. Our comparison is two-fold. First, we compare deliberative governance initiatives in the different state traditions of the Netherlands and UK. Second, we compare the newly set up deliberative governance initiative to an existing policy regime mainstreaming climate adaptation in a similar state tradition, in our case the Netherlands. We find that: (1) Deliberative governance initiatives in the (neo-)corporatist state tradition of the Netherlands yields learning but shows apathy among politically elected decisionmakers compared to deliberative governance initiatives in the pluralist state tradition of the UK where clearly defined rules and responsibilities yields negotiation and action; (2) A typical corporatist policy regime mainstreaming climate adaption in a (neo-)corporatist state tradition yields effective and legitimate policy formation but lacks learning.
\end{abstract}

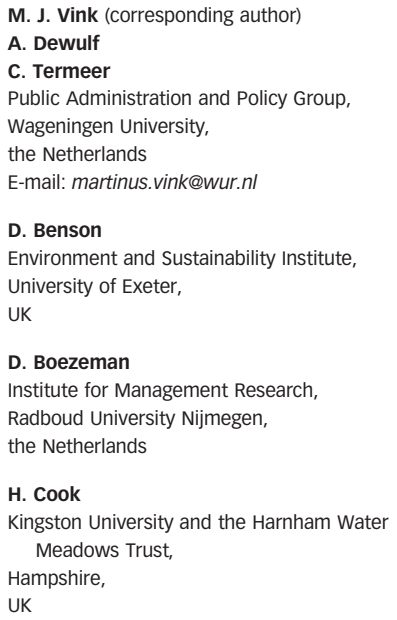

Key words | adaptive water management, climate adaptation, deliberative governance United Kingdom and the Netherlands, frame analysis, participation, powering, puzzling

\section{INTRODUCTION}

The plurality of problem definitions or frames employed in the societal discussion about adaptation to climate change sparked proposals for more deliberative initiatives of climate adaptation governance. These horizontal forms of network centred policy formulation are claimed to do justice to this plurality in societal frames through deliberations between public and private players compared to traditional institutionalised state centred decision-making (Hulme 2009; Rojas et al. 2009; Roncoli et al. 2009; Dryzek 20Io; Manuel-Navarrete 20IO; Feldman 20I2). In addition to this normative standpoint, the openness to societal players and the capacity to learn over various frames in deliberative governance initiatives is believed to bring effective and legitimate adaptation policies (Shackley \& Deanwood 2002; Nelson et al. 2008; Tompkins et al. 2008; Pahl-Wostl 2009; Dovers \& Hezri 20Io; Vink et al. 20I3a, 20I3b).

However, even though climate adaptation emerged on the policy agenda only recently, climate adaptation is not a standalone issue but is generally dealt with in existing state centred policy fields such as flood safety or freshwater availability. The governance of climate adaptation and its accommodation of societal frames and vested interests traditionally depends on how state centred policy making is organised. Following literature on the role of the state in society, Adger et al. (20I3) have referred to cross national differences in state-society relations as different 'social 
contracts' determining a division of responsibilities, powers and mutual expectations in climate adaptation. Similarly, scholars in the field of policy sciences have discussed the crystallisations of long term patterns of 'intermediation' between the state and societal interest through institutions and policy making routines (Schmitter 1974; Wilson 1983). These 'state traditions' vary in their institutionalised patterns of mutual dependencies between society, organised interest groups and the state, and therefore yield different institutional arrangements, or 'policy regimes' of norms and interaction patterns (Schmitter 1974; Dyson 1980; Wilson I983; Koppenjan \& Klijn 2004; Howlett 2009; Massey \& Huitema 20I3; Biesbroek 20I4). Proposing more deliberative governance initiatives as uniform ad hoc arrangements for effectively governing the various societal problem definitions associated with the emerging issue of climate adaptation therefore raises questions on how this empirically fits different state traditions and compares to existing policy regimes addressing climate adaptation.

While we do not aim to draw generalizable conclusions as to what causes differences in deliberative governance initiatives, or aim to add to the well-established body of literature on state tradition or policy styles, we do take this literature as an intriguing background to understand processes of deliberative governance initiatives in the emerging field of climate adaptation, and what might explain cross-state differences. Therefore, this paper takes a qualitative approach to gain an in-depth understanding of how new deliberative governance initiatives are set up and how these function in different state traditions. The paper compares deliberative governance initiatives in terms of (1) institutional arrangements, (2) players involved, and (3) deliberative processes. To understand differences between deliberative governance and traditional policy making, the paper compares deliberative governance with existing policy regimes dealing with climate adaptation challenges in the same state tradition. We focused on water management in the UK and the Netherlands. Firstly, water management represents a typical policy field in which climate impacts are expected to materialize and within which new deliberative governance initiatives proliferate. Secondly, both countries share geographical characteristics of lowland coastal areas prone to sea level rise and changing precipitation patterns, yet have different traditions in state organisation and water management policy regimes (Wilson I983; Cook 1998; Kuks 2002).

The paper poses two questions: (1) How do framing processes and player involvement of a deliberative climate adaptation governance initiative in the Dutch neo-corporatist state tradition compare to framing processes and player involvement of deliberative climate adaptation governance initiatives in the British pluralist state tradition? (2) How do framing processes and player involvement in deliberative governance initiatives of climate adaptation compare to the framing processes and player involvement in traditional water management policy regimes taking care of climate adaptation in Dutch neo-corporatism? For answering these questions the next section of this paper will elaborate on the conceptual foundations of state traditions and policy regimes, which we contrast with scholarly ideas on deliberative governance. We propose framing theory as cross-cutting for understanding how deliberative processes actually play out in different institutional contexts. After that we describe our methodological approach, case study selection and how we conducted field research. In our results section we contextualise our conceptual framework for climate adaptation in the Dutch and British, context after which we zoom in on three concrete climate adaptation governance case studies and draw conclusions on how both state traditions affect the deliberative governance processes under study.

\section{STATE TRADITIONS, POLICY REGIMES AND DELIBERATIVE GOVERNANCE INITIATIVES; CONCEPTUAL FOUNDATIONS}

\section{Institutionalised interest intermediation}

Where in continental European history the state gained a central role as an idea and an institution safeguarding the nations' public interest, in the Anglo-Saxon world such as the UK the state remained relatively underdeveloped in taking care of this national public interest. Contrary to continental European tradition, where on a philosophical level some authors claim the state to be an administrative institution which is positioned 'in-between' the politically elected government and the governed, policymaking in the 
UK can be understood as the direct execution of parliamentary will. In theory this means that despite heated opposition a (regional) majority interest can win without interference of 'a state' as an institution representing the nations' 'collective' interest (Dyson 1980). Specific societal interests might also compete for policy making power outside of parliament but through regulated forms of what Schmitter (I974) defines as 'interest intermediation' between the state and organised interest groups. Classical policy studies focussing on systems of interest intermediation highlight the cross national variations in these systems as different 'state traditions' and distinguish concrete policy regimes of institutions, regulation and underlying organisational values within these state traditions that more or less correspond with policy making traditions (Heclo 1974; Schmitter 1974; Dyson I980; Wilson 1983; Howlett 2009). The Dutch tradition in interest intermediation between the state and society can be characterised as an institutionalised negotiation process between a limited number of organised vested interests and the state, often referred to as (neo)corporatism, or in Dutch 'the polder'. In the UK however, the tradition in interest intermediation is referred to as pluralism, showing much less institutionalised patterns and more room for a wide variety of societal interest groups to compete for a place in the policy making process outside parliament (Schmitter 1974; Wilson 1983; Visser \& Hemerijck 1997; Prak 2008; Lijphart 20I2; Prak \& Luiten van Zanden 20I3).

\section{Deliberative governance initiatives}

Apart from prolonged institutionalized patterns in interest intermediation discussed as state traditions and policy regimes, scholars in policy sciences have highlighted an empirical trend towards less institutionalized practices of interest intermediation and policy making. Although conceptually still imprecise, these forms of governance can be characterized processes of deliberations through interorganizational networks which come with a withdrawing state government (Kickert et al. 1997; Rhodes 2002; Sabatier 2005). Contrary to the institutionalized negotiations that characterize state traditions like corporatism, this form of governance may be conceptualized as institutionally 'decentred', or network centred, in the sense that the institutional capacity to regulate the process of governing remains under developed: Policy outcomes are less dependent on a sovereign regulating authority responsible for decision making, but more on a marked like co-production of equal players negotiating trough language (Bevir \& Rhodes 2003; Howlett 2009). This empirical notion of a decentred or network approach to policy making correlates with the definition of deliberative governance often prescriptively adopted in climate adaptation studies as discussed in our introduction section. Because these prescribed deliberations go beyond empirically observed genuine trends towards more 'decentred' governance, we choose to focus on intentionally initiated governance deliberations between public and private players. We defined these initiatives in line with Dryzek (2010) as deliberative governance initiatives that are increasingly employed by governments to involve society in policy making in different ways than through democratic elections or institutionalized forms of interest intermediation. These initiatives often get shape as temporal policy programmes discussed above, but may also concern more structural decentralizations of policy execution toward a wide variety of regional or local public and private players. In all cases deliberations take place in-between institutions rather than within. However, not all state traditions or policy regimes seem to allow for ad hoc deliberative governance initiatives. Where pluralist traditions show similarities with deliberative governance considering a wide variety of societal players traditionally involved and a relatively moderate role for the central state, corporatist traditions show a stronger role of the state, a high degree of institutionalization, hierarchy and a limited amount of preselected societal players involved.

\section{Mainstreaming or ad hoc deliberation: operationalizing the climate adaptation policy process}

As Biesbroek et al. (20I0) has indicated, different governments have adopted different approaches to govern societal adaptation to a changing climate. These differences may become visible through ad hoc deliberative governance initiatives, but often got shape as extensions of existing policies or as a new element in existing policy regimes. Scholars have labelled these extensions as forms of mainstreaming (Smit \& Wandel 2006; Swart \& Raes 2007). Mainstreaming climate adaptation will leave traditional 
policy regimes and corresponding systems of interest intermediation largely unchallenged. Ad hoc deliberative initiatives however, might contrast with or parallel traditional policy regimes as it might involve new players, new ad hoc routines and potentially bypasses existing policy regimes, or has to feed back into existing regimes for official decision-making. Understanding tangible differences between policy processes mainstreamed in existing regimes or initiated as deliberative governance requires a shift in focus toward the practical level of players actually interacting in the policy processes. To allow us to reconstruct the differences in processes of policy making and corresponding interest intermediation in different contexts we draw upon the work of Heclo (1974) and others (Hall 1993; Visser \& Hemerijck 1997; Culpepper 2002) that understand player centred processes as an interplay of puzzling over what is at stake, and powering over who gets what position in the policy process. Hoppe (20II) adopted the idea of policy players puzzling and powering in a more 'on the ground' definition of policy making through deliberations with society. According to Hoppe and others the question who participates in defining or 'framing' what is at stake can be considered central to concrete processes of puzzling and powering (Schön \& Rein 1994; Hoppe 20Ir; Dewulf 2013; Vink et al. 20I3a, 20I3b). Frames take shape as short storylines or metaphors, explicitly or implicitly saying something about the cause of the problematic reality -what is- and at the same time take a moral standpoint towards this reality pointing towards possible solutions -what ought to be. Accordingly, in policy deliberations in whatever state tradition, policy regime or deliberative governance initiative, a frame may function as a puzzling device in defining what is at stake, but may at the same time help organizing power by defining the issue at stake and posing a moral standpoint towards the issue at stake in relation to the other players and frames involved in the policy process.

\section{METHODOLOGY}

\section{Methodological approach}

We applied a qualitative constructivist approach in doing comparative case study research. We did so for gaining in-depth understanding how processes of deliberative governance initiatives play out in different state traditions, and how these processes compare to climate adaptation mainstreamed in existing policy regimes. Although we are aware of the limitations of case study research in drawing general conclusions on cause-effects in policy research, we follow Flyvbjerg (2006), Gerring (2004) and Thomas (20II) in their assessment of comparative case study research as a method for gaining understanding of the non-linear indepth relations between a wide variety of variables in context. We apply case study research to nuance general theory and intuitions on deliberative governance initiatives in the emerging field of climate adaptation. To do so we conduct two separate comparisons: (1) similar deliberative governance initiatives in the emerging field of climate adaptation are compared on the basis of different state traditions in which they are embedded, and (2) a deliberative governance initiative in the field of climate adaptation is compared to an existing policy regime that mainstreams climate adaptation in the same state tradition.

Because the neo-corporatist state tradition is theoretically most distinct from the open character of deliberative governance, we took a Dutch deliberative governance initiative of climate adaptation in regional water management as our point of departure. For the selection of our second comparable deliberative governance case in a different state tradition we chose a British regional initiative in relation to water management for its comparable geographical characteristics and its state tradition being different from the Dutch tradition and more closely related to the limited role of the state as represented in deliberative governance (Dryzek 20I0). For our second comparison we once more took the Dutch deliberative governance initiative as our point of departure which we this time compared with climate adaptation taken care of in the existing regional Dutch water policy regime. With this second comparison we were able to understand the empirical difference between what we theoretically defined as a deliberative governance initiative and policy making in a traditional policy regime which mainstreams climate adaptation in existing policies.

\section{Case selection}

For the first comparison we selected two cases which represent different state traditions but share novel deliberative 
governance initiatives on water management adaptation to climate. In the case of (neo-)corporatist Netherlands we selected the governmental initiated multilevel deliberative governance initiative of the Dutch Delta Programme for the Ijsselmeer region (DPIJ). We selected this programme because it represents a rather innovative and unique, limited institutionalized horizontal deliberative governance approach in the Dutch (neo-)corporatist context which corresponds with what is often proposed in climate adaptation literature. The initiative materialised in form of a policy programme relatively open to any regional societal players willing to participate. This resulted in representatives of various governmental sectors and layers, as well as civil society representatives, stakeholders and political elected decisionmakers deliberating over how climate adaptation should take place in the lake they all geographically related with (Delta Programma Ijsselmeergebied 20I; Ijsselmeergebied 20II; Vink \& Mulligen 20I3; Van Buuren et al. 2014).

For pluralist UK we selected the deliberative governance initiative embedded in the Regional Flood and Coastal Committees (RFCCs) of Anglia in the UK. We selected this initiative because it represents a novel deliberative governance approach to climate adaptation in water management compared to earlier national agency centred policy making in the same field. Contrary to the unique deliberative governance initiative in the Dutch climate adaptation context, our British case represents a much wider applied initiative. Throughout most of the low laying parts of the UK the RFCCs are characterised by regional and local public and private players deliberating over how climate adaptation should take place in water management without national government taking the lead. This comparison could yield in-depth understanding of how deliberative governance initiatives can become institutionalised and how this relates to the state tradition.

For our second comparison we selected the unique deliberative governance initiative in the Netherlands discussed above, which we compared with a traditional water management policy regime in the Netherlands dealing with climate adaptation and referred to as 'Dry feet 2050'. We selected Dry feet 2050 because it can be classified as an archetypal Dutch regional governmental centred programme on flood safety issues which mainstreams the potential impacts of climate change in their flood safety policies (Boezeman et al. 20I4). The programme is characterised by institutionalised decision-making. In line with the (neo-)corporatist state tradition the provincial authority takes the lead in this regional programme and water board authorities follow together with a couple of traditionally determined preselected organisations representing vested interests. Deliberations take place through hierarchical institutionalised decision-making patterns and informal routines.

\section{Data collection and analysis}

We collected data during the policy trajectories under study. For the Dutch cases we conducted research between 2010 and 2013, which overlaps with the programme duration of DPIJ (2010-2014) and Dry feet 2050 (2010-2014). For the British case interviews were conducted and document analysis was done during the same period. Our data consisted of three parts. We used project documents and textual information on the institutional arrangements of the projects. We additionally used textual recordings or notes of project meetings, stakeholder meetings and steering committee meetings. This was complemented by interviews with project officials and key stakeholders.

To determine how concrete policy processes played out in (neo-)corporatist compared to pluralist state traditions, or deliberative governance initiatives compared to existing policy regimes we describe: (1) the institutional arrangements embedding the policy deliberations - this includes laws, regulations and ad hoc project rules and responsibilities; (2) the corresponding players involved in the deliberations - we describe what responsibilities public officials and private players have, what roles they play, and whether and how these change during the process; (3) the framing processes that follow the previous and characterizes the deliberations. We discuss problem framing, meaning how the problem is officially framed, how these framings develop during the interaction processes (Schön \& Rein 1994; Dewulf et al. 2009; Vink et al. 2013a), and scale framing, relating to the problem scales different players use during the process (van Lieshout et al. 20II) and what the implications of these framings are for player dependencies and negotiations.

We started with the theoretically odd case of deliberative governance in the theoretically defined (neo-) 
corporatist state tradition of the Netherlands, which we compare with a comparable governance arrangement in British pluralism of the UK. To understand the empirical difference of what we theoretically defined as deliberative governance in the Netherlands, we followed our first comparison with a second comparison with a traditional policy making regime mainstreaming climate change in its policies. In both comparisons we used the same indicators for classifying the deliberative process and the institutional arrangements. The method of analysis is summarised in Figure 1.

\section{CONTEXTUALISING DELIBERATIVE GOVERNANCE INITIATIVES IN DUTCH AND BRITISH CLIMATE ADAPTATION}

In 2008 a national state committee set climate adaptation firmly on the Dutch political agenda. However, no overall national climate adaptation policy was formulated. Instead, the committee framed the issue as a central element in existing water management policy which resulted in a national act concerning flood safety. Due to the lack of an overall national climate adaptation policy, climate adaptation gained little attention in other policy fields and became primarily a national water issue (Boezeman et al. 20r3; Vink et al. 2orza; Biesbroek 2014). This implied that climate adaptation was taken care of in the national water management policy regime. In line with the Dutch (neo-)corporatist tradition this policy regime shows an institutionalised decisionmaking tradition from medieval periods onwards in which vested interests play a central role through local water boards. However, with a changing climate emerging on the policy agenda and some recent high-water events, the Dutch government not only developed new flood safety legislation but also started deliberative governance initiatives regionally, which paralleled the (neo-)corporatist policy regime. Initiatives like Room for the River and more recently the Dutch Delta Programme for Lake Ijssel reflect a tendency to organise policy formulation and implementation in a more decentralised open ad-hoc fashion (Dolfing \& Snellen r999; Disco 2002; Koningsveld et al. 2008; Kuks 2009; Bourblanc et al. 2012; Buuren et al. 2012; Prak \& Luiten van Zanden 2013; Vink et al. 2013a, 2013b).

\begin{tabular}{|l|l|l|l|} 
Indicator & $\begin{array}{l}\text { Case 1 } \\
\text { Deliberative } \\
\text { governance initiative } \\
\text { of the "Delta } \\
\text { Progromme } \\
\text { Ijsselmeer" } \\
\text { In corporatist } \\
\text { Netherlands }\end{array}$ & $\begin{array}{l}\text { Case 2 } \\
\text { Deliberative } \\
\text { governance initiative } \\
\text { of the "Anglion } \\
\text { Regional Flood and } \\
\text { Coastal Committees" } \\
\text { in British pluralism }\end{array}$ & $\begin{array}{l}\text { Case 3 } \\
\text { Traditional policy } \\
\text { regime mainstreaming } \\
\text { climate adaptation } \\
\text { through "Dry feet } \\
\text { 2020" in corporatist } \\
\text { Netherlands }\end{array}$ \\
\hline $\begin{array}{l}\text { Institutional } \\
\text { arrangement }\end{array}$ & & & \\
\hline Actors involved & & & \\
\hline $\begin{array}{l}\text { Framing and } \\
\text { interaction patterns } \\
\text { during policy making } \\
\text { process }\end{array}$ & & & \\
\hline
\end{tabular}

Figure 1 | Comparative analysis of deliberations in climate adaptation governance. 
In the UK the emergence of climate adaptation on the policy agenda resulted in the formulation of a national climate act, which at a national level went beyond specific policy fields. Contrary to the Dutch context, the act enhanced a rather managerial approach to climate adaptation as a crosscutting regional issue. By formally decentralizing climate adaptation responsibilities, regional public and private organizations were assigned to make policies at their administrative scale. National government only coordinated their regional activities in various policy fields towards nationally set values (Swart \& Raes 2007; Tompkins et al. 2010; Boyd et al. 20II; Massey \& Huitema 20I3; Biesbroek 20I4). This resulted in climate adaptation being mainstreamed in regional water management policy making. Corresponding with this pluralist approach, British flood protection shows a policy tradition where for a long time local society rather than the state operated as the primary policy player (Cook 1998, 2010; Dryzek et al. 2002; Pottier et al. 2005; van Buuren et al. 2012). Centuries after the Dutch started to centralise flood management through state organisations, in 1930 centralisation of tasks began to occur in England by the establishment of the national Land Drainage Act. The act involved the establishment of regional Catchment Boards to provide flood defences and drainage in certain areas (Cook 1998, 2010). The creation of Regional Water Authorities in 1974 led to flood control tasks becoming shared between these regional entities, local authorities and internal drainage boards (IBDs) (Benson et al. 2013a, 2013b). Although pluralist in terms of the variety of (societal) organisations involved, deliberation in decision-making became restricted to rather technocratic regional authorities and IDBs, whose umbrella group, the Association of Drainage Authorities, was seen as dominated by land-owner vested interests (Purseglove \& Britain I988). This regional governance structure was reformed under the Water Act 1989, and came in 1996 under the supervision of the Environment Agency (EA). Regional Flood Defence Committees (RDFCs) were also created alongside the centralised EA, comprised of Agency players and local authority representatives. Despite the often discussed pluralist British state tradition, at this point centralised state control negotiating with vested interests made the water policy regime actually seem more corporatist than pluralist. Similar to the Dutch situation, climate change in combination with high water events in 2007 made the British government reconsider its flood protection policy regime and proposed elements of deliberative governance.

\section{(DELIBERATIVE) GOVERNANCE OF CLIMATE ADAPTATION IN THREE CASES}

\section{Case 1: deliberative governance initiatives in a (neo-) corporatist state tradition: 'the Dutch Delta Programme ljsselmeer'}

The Dutch state committee drafted an advisory report to the Dutch government in 2008. The report was based on rather extreme climate scenario's pointing towards an urgent need to 'climate proof' the low laying Netherlands, accommodating a majority of its 17 million inhabitants and economic activities at or below sea level (Delta Commissie 2008; Boezeman et al. 20I3). With the strong emphasis on climate change as the main reason for action high on the political and societal agenda, the framing of the advisory report supported the committee in legitimizing its drastic recommendations (Vink et al. 2013a, 20I3b). In line with the Committee's drastic recommendations the Dutch government initiated the Delta Programme in 2010.

\section{Institutional arrangement}

The Delta programme is coordinated by a special state official ('Delta Commissioner') who acts under the responsibility of the Minister of Public Works and is legitimized by new national legislation; a Delta Act (Delta Programma 20Io). The Delta Commissioner is to prepare so-called Delta Decisions to be made by government every five years (Delta Programma 20I0). One Delta Decision, planned for 2015, is whether to raise the water level in the country's largest freshwater lake 'Ijsselmeer' by 1.5 meter. The initial plan of raising the lake's water level was put on the policy agenda by the Delta Committee aiming for an enlarged freshwater reservoir anticipating increased future summer droughts and to a lesser extend increased flood safety in view of decreasing discharge capacity to the raising sea level of the adjacent Waddensea. Accordingly, the Delta Programme contains a sub-programme for the Ijsselmeer 
region (DPIJ), which has been established to prepare the Delta Decision parallel to constitutional decision-making structures. The decision could heavily impact on several waterfront towns with low-lying traditional quays and harbours attracting many tourists. However, some nature reserves also face permanent inundation in case the intended $1.5 \mathrm{~m}$ rise in water level will be sustained, and some low-lying industrial areas face flooding (Delta Programma Ijsselmeergebied 20II).

Anticipating the potential impacts on the region, regional governments adjacent to the lake organized themselves in an 'Ijsselmeer'-group opposing the initial plans. After the establishment of DPIJ this Ijsselmeer group was incorporated in a broad deliberative governance network of about 300 public and private players initiated by an administrative office established for DPIJ. The administrative office was made accountable to a steering committee consisting of four appointed representatives from all regional politically elected decision-makers. The DPIJ deliberations were presented as a bottom-up governance process (Delta Programma 20Io). As the deputy director of the DPIJ explained to over 100 public and private players in one of the first network meetings, 'climate is changing, the Ijsselmeer water system is running into its limits, and we want to cooperate with you in finding ways to adapt the water system'.

\section{Player involvement}

During the first phases of the programme the stakeholder meetings were set up by the DPIJ administrative office as knowledge-sharing meetings. Over 300 public and private players from the Ijsselmeer region were invited to get to know each other and to share knowledge about their insights in the lake's water system. Players concerned regional administrators, experts, regional politically elected decision-makers and representatives of societal interest groups and business. Although the players were given ample room for discussing, setting agenda's and taking part in workshops, the administrative office organized most meetings, sent invitations, and hence operated as a gatekeeper organization (Bache et al. 1996; Bache 2000; Barzilai Nahon 2008). In the final phases the network meetings were meant to develop preferable long-term strategies for achieving the Delta Programme goals of a safe and drought-proof Netherlands (Delta Programma 2010). Political decision-making, however, had to take place in the constitutional decision-making structures of municipalities, water boards, provinces and the state.

Initially the sense of urgency with the stakeholders was rather high, as was the number of participants. Because the Ijsselmeer region did not exist as an administrative entity in terms of policy regime prior to the consultation, most public and private players experienced the first network meetings as novel and valuable in crossing institutional boundaries. However, during the formulation of plausible strategies, urgency and participation of various public and private players gradually faded.

\section{Processes of framing}

After the Delta Committee put the Ijsselmeer region on the policy agenda as a national security issue, the national civil servants and experts from the DPIJ administrative office reframed the security issue into an 'upgrading the water system' frame, for which in view of a changing climate, 'doing nothing was not an option'. By setting the boundaries of the deliberations in form of a technical 'upgrade' of a national scaled interest, the administrative office defined the players who were the plausible holders of relevant pieces of the puzzle: the mostly national and regional public administrators directly involved in the technical or procedural characteristics of the system. In addition, by framing the issue as a national 'system' wittingly or unwittingly, the administrative office put technical experts in charge leaving less room for political elected decisionmakers lacking the technical knowledge to join in solving a 'technical puzzle'. Regional political elected decisionmakers struggled with reframing the technically defined 'system' issue into a regional scaled societal or political issue. Repeatedly public and private regional players asked the DPIJ administrative office to be clear about the water level as preferred by the national government on the medium-long term, or to be clear about the decisionmaking procedures, allowing the societal and political players to position themselves towards this new proposed reality. The administrative office however, was hesitant in taking a stand about national preferences or official 
procedures. In line with the technical framing they focused on the fine-tuning of various plausible strategies covering a broad range of hypothetical water levels and time lines (Vink \& Mulligen 20I3). Subsequently some political players failed to see societal and political sense reflected in the process and indicated they might withdraw from the network meetings and turn to backchannel lobbying at the national political level (Vink \& Mulligen 2013).

\section{CONCLUSION}

Because the national civil servants became the gatekeeper and the agenda setter discussions remain technical. Although regional societal representatives and political elected decision-makers tried to reframe this into more institutional or political meanings, the framing in the discussions remained non-political. For the administrative office, framing the puzzle in a non-political way sidestepped the danger of political controversy. However, the technical framing in combination with the administrative office not taking stances yielded ambiguity in national aims and corresponding ambiguity in mutual dependencies. This discouraged regional societal and political elected decision-makers from sharing their local societal and economical concerns and negotiating over these concerns in the deliberations. This led to a flaw in attention and occasional withdrawal from the voluntary network meetings.

\section{Case 2: deliberative governance initiative in British pluralism: The Anglian regional flood and coastal committees in the UK}

Acting on the Pitt Report in 2008, the British government introduced the Flood and Water Management Act in 2010, which gives unitary or county authorities the lead responsibility for managing local flood risks (as Lead Local Flood Authorities or LLFAs), encouraging local engagement in flood control in view of climate adaptation, investment decision-making and 'stronger partnership working' (National Audit Office 20II) In addition, RFCCs were established. These RFCCs govern the deliberations between the $\mathrm{EA}$, and the LLFAs and other relevant players in governing risks. Twelve RFCCs have been established across England. For reasons of geographical similarity with Dutch lowland areas, we will focus only on the Anglian region in eastern England (Table 1). Covering more than $27,000 \mathrm{~km}^{2}$, it is comprised of mainly high quality agricultural land extending across several counties. Although the driest EA region in terms of rainfall, there are particular issues surrounding flooding as most of the land is flat and low-lying, with 25\% below sea level (Environment Agency 20I2). The north Norfolk and Suffolk coast is also particularly vulnerable to sea erosion while saline inundation is an ever-present threat to the Broads; a protected area of waterways popular with tourists. To compound these risks, the region is home to six million people and has the fastest expanding population in England and Wales. The region contains three RFCCs: the Northern, Southern, and Eastern.

\section{Institutional arrangements}

Established by the EA under obligations in the 2010 Act, the RFCC statutory committees provide a lead in deciding flood control programmes in their region. According to the Government (Gov.uk 20I3), RFCCs are responsible for producing plans that identify flood and coastal erosion risks, targeting investments to reduce such risks and providing a coordinating link between the EA, lead local flood authorities and other relevant players in governing risks. The EA must consult with the RFCC on conducting its flood and coastal management functions, take into account the committee's decisions in performing these functions, obtain the permission of the committee when setting a

\begin{tabular}{|c|c|c|}
\hline $\begin{array}{l}\text { EA } \\
\text { region }\end{array}$ & $\begin{array}{l}\text { Regional flood and } \\
\text { coastal committee }\end{array}$ & Player composition (seats) \\
\hline \multirow[t]{3}{*}{ Anglian } & Anglian (Northern) & $\begin{array}{l}1 \text { independent chair } 8 \text { EA expert } \\
\text { appointees } 10 \text { local authority } \\
\text { representatives }\end{array}$ \\
\hline & Anglian (Central) & $\begin{array}{l}1 \text { independent chair } 6 \text { EA expert } \\
\text { appointees } 8 \text { local authority } \\
\text { representatives }\end{array}$ \\
\hline & Anglian (Eastern) & $\begin{array}{l}1 \text { independent chair } 8 \text { EA expert } \\
\text { appointees } 10 \text { local authority } \\
\text { representatives }\end{array}$ \\
\hline
\end{tabular}


levy and spending funds in the region. Although the majority of EA flood defence expenditure comes direct from national government, since 2011 not all schemes are centrally funded meaning the Agency can seek 'match' funding from local authorities via a Local Levy. Committees also review local authority flood risk assessments and management strategies to ensure coordination between the local and regional levels, and consistency with the national strategy. The EA still maintained overall national responsibility for managing river and coastal flooding risks in view of climate change. A key coordinating mechanism in this respect is the National Flood and Coastal Erosion Risk Management Strategy with its focus on adaptation to climate change, and at a regional level the RFCCs.

\section{Player involvement}

While meetings are open to the public, RFCC membership and input to decision-making is restricted to local authorities and player groups pre-determined by the EA. Committee chairs typically are independent local experts appointed by the Secretary of State for Environment (head of the environment ministry or Defra) or the Welsh Government. Committees are comprised of a mixture of conservation group players, farmer and land owner representatives, inland flooding experts, coastal flooding experts - appointed by the EA - and councillors from local lead local authorities in the region (Table 1). Player involvement is therefore not as dominated by vested interests as in Dutch (neo-)corporatist approaches. That said, this approach is only relatively recent: the committees are more pluralistically 'democratic' than their previous incarnations (RFDCs) as they now provide strong input for directly elected local councillors alongside epistemic players. This input is particularly important because, as mentioned, RFCCs raise a levy on local authorities to help fund selected priority flood management schemes.

Institutional membership type varies slightly between the three committees in the Anglian region (Table 1). For example, the Anglian Eastern committee is comprised of a chairman, eight Agency appointed players, including conservationists, farmers and flooding experts, and local councils officials from the LLFAs (Essex, Norfolk and Suffolk county councils) plus Southend and Thurrock councils.
Committee meetings are generally convened every three months and are relatively well attended by committee and non-committee members. Data is unavailable on how many members of the public attend the meetings, although evidence from this region suggests that they are largely absent.

\section{Processes of framing}

Framing of flood management issues by committees is partly determined by national strategic objectives, central government funding and, increasingly, local spending and flood defence priorities. A visible process of reframing occurred after the Pitt Review, with the government perceiving flood governance more in terms of localised stakeholder input to decision-making and partnership working. Although this reframing did not alter the scale of regional governance structures, as the RFCCs replaced the RFDCs, it did lead to the re-organisation of committees to include greater local authority participation. This 'partnership' frame to both funding and managing flood controls has to an extent altered local authority roles. Regional priorities are set by the National Strategy, published in 2011 but local authorities appear now to have greater influence over targeting of investments for their priority projects. Analysis suggests that local flooding concerns are being addressed in the committee decision-making. For example, in the Anglian region the EA has had to consult with the committee to a greater degree than in the past on its regional programme and spending, although the partnership approach was already evident before the institutional changes. According to the Agency (Environment Agency 2012), it has been 'working with stakeholders to build strong working relationships to ensure a co-ordinated approach' in the region. As a result, all five LLFAs in the Anglian Eastern Region were able to complete preliminary flood risk assessments and local flood risk management strategies - the latter in conjunction with other stakeholders and the public. These documents will underpin future committee decision-making in the region. While the post-Pitt era has therefore witnessed a reframing of the floods issue towards a more 'local' understanding of the problem in regional governance structures, there is still an element of centralised agency control. 


\section{CONCLUSION}

Deliberative processes in the RFCCs could be seen as broadly representative of a pluralist state tradition typically associated with the UK. The committees involve both state agency, agency appointed and elected local authority players in managing flood defences, ensuring some degree of local democratic representation in decision-making alongside a legally limited role for the state. However, this form of deliberation has not always characterised flood management in England and Wales where the influence of central state players and vested interests has been historically more prominent and certainly has strong similarities with the Dutch (neo)corporatist tradition. In addition, the main implementing player in inland and coastal flood defences is still the EA, providing an indicator of relative power in decisions taken. Nevertheless, responsibilities of the local organisations involved are set by national acts and deliberations show framings that lead to negotiation and ultimately action.

\section{Case 3: climate adaptation regionally mainstreamed in a traditional water management policy regime of a (NEO-) corporatist state tradition: the Netherlands, 'dry feet 2050'}

In early 2011, the Provincial Councils of the Dutch Northern provinces Groningen and Drenthe were informed by their administrators and the geographically corresponding waterboards Noorderzijlvest and Hunze an Aa's on a follow up study of their previous five yearly regional flood safety updates. These HOWA studies focused on so called secondary or regional water barriers which concern smaller inland water systems, which are mainly rain fed. The update study was relabelled as DV2050 (Dutch for Dry Feet 2050). The policy letters formulated four direct reasons for the relabelled update. First, the HOWA studies did not deal with the long term, especially with respect to climate change and soil subsidence. Second, the Province of Groningen decided in 2005 that it wanted to strive for higher safety norms for regional water barriers to be 1:300 and 1:1,000. Third, the models used in the previous studies advanced and provide water levels that differ from the older models. Fourth, the regional barriers are to be periodically tested. Following the strategic provincial environmental plan for 2009-2013 in which climate adaptation was labelled as a central goal, the problem scope of the project was clearly embedded in a climate adaptation narrative.

\section{Institutional arrangement}

Besides taking up climate change in the existing regional policy regime, the DV 2050 project differs slightly from previous HOWA studies with respect to its intentions for stakeholder participation. The start-up document states that preselected stakeholders will be involved as early as possible in order to gain acceptance for the end result and to find solutions that are 'integral' and 'innovative' (Stuurgroep Droge Voeten 2050 20II). The strategy is a direct response to the experiences with the societal resistance the civil servants encountered in the previous HOWA studies and succeeding policy implementation. Despite these reframings towards climate change and stakeholder participation, the basic institutional constellation of rules, roles and competencies of the project remains very close to its predecessor, which are formalized in a the Water Act (2009) and several National Government Accords on Water (2003, 2008 and 2011). The participating governments are the same, the provinces of Groningen and Drenthe and the waterboards Noorderzijlvest and Hunze and Aa's, as well as the geographical problem scope of the project. As a matter of routine, the steering group consists of decision-makers from the involved four governments. The steering group makes political decisions and regularly involves the administrators of the provinces and water boards (Boezeman et al. 20I4).

\section{Player involvement}

The project group of civil servants prepares decisions and operates with sub-projects for which the vested interests in region are invited as a matter of routine. These are the branch organization of farmers LTO, the umbrella organizations for nature and environmental groups, the organization of the municipalities and the committee on soil subsidence and energy related organisations (the area of concern is the largest gas mining area in the Netherlands, involving various large infrastructural works and the issue of soil subsidence due to mining). These organisations are 
labelled as 'priority stakeholders'. The priority stakeholders receive the agenda of the project group meetings, may raise new agenda issues and are welcomed to comment, which they occasionally do. One sub-project leads the defining safety norms and two deal with developing adaptation policies for the water systems of the two water boards. Those sub-projects initiate studies by knowledge institutes and consultants for specific expertise or calculations.

The project group coordinates and sets the preconditions for the adaptation policies studies in consultation with the priority stakeholders. From the start onwards, the ambition in DV2050 was to intensify stakeholder interaction in this project vis-à-vis the earlier HOWA studies. The stakeholder kick-off event was well-attended, but the sense of urgency for the problem of the project was low. In part this was due to a lack of concreteness of showing what the consequences of climate change were for the water system or for stakeholders. For another part, the tradition of the state providing safety for its inhabitants in a rather corporatist manner was effective and non-controversial, and accordingly the general goal and organisation of the project was non-disputed (Boezeman et al. 20I4).

In all phases of the project the technical and participatory trajectories are clearly separated. Contrary to the overall project group organisation where ideas and policy preferences are formulated, the technical trajectory of the sub groups is expert-dominated. In these sub-groups the different packages of policies developed in the project group are considered by assessing their hydrological, economic, environmental, cultural heritage, and agricultural effects, also in view of future climate change. The administrators then propose the technically best assessed policies to their parliaments for decision-making. Here, we observe a classical feature of Dutch (neo-)corporatist policy making, where experts delineate the substantial playing field in which players may bargain (Halffman 2009).

\section{Processes of framing}

As discussed above, officially the DV 2050 project is framed as a periodic update of the water safety system in view of climate change. During the process this framing translates in various problem framings held by various players at various scales: (1) an update of the hydrological models is the problem, (2) the new norms as set by the province cause the problem of living up to these norms, and (3) land use is the problem. In addition the problem framings translate in institutional framings, (1) on allocation of responsibility, (2) on budgets, and (3) on how to influence decision-making. What is striking is the rather adversarial character of the interactions of the players in the project group holding these different frames. Most project group meetings of about 3 hours where characterised by one or more conflicts: problems were discussed but responsibilities and budgets were often actually negotiated over or temporally set aside if deadlocks were looming. There was little change in this character during the three years we followed this project. Discussions often yielded conflict and negotiations. However, no civil servant or primary stakeholder left the process, and most meetings yielded (incremental) progress in the formation of a collective agreement on how to update the water system in view of climate change. Most interactions of conflicting frames took place as part of a policymaking routine with clear procedures and were characterised by relatively clear organisational dependencies and responsibilities.

\section{CONCLUSION}

Although various governments and stakeholders are involved, the policy regime has a rather routinized character. Meetings and procedures are clear to players involved and follow interaction-routines. Player selection for participation is typically (neo-)corporatist in the sense that 'priority' stakeholders are invited to take part in meetings, are known by governmental players and represent powerful organised societal interests. The initial regionally scaled problem framing is contested by other framings in a rather adversarial manner during regular meetings. However, due to clearly defined roles, responsibilities and interdependencies, frame differences yield negotiations rather than apathy or controversy (Boezeman et al. 2014).

\section{COMPARISON AND DISCUSSION}

The results summarised in Table 2 show clear differences and similarities between the three cases. In line with 
Table 2 | Comparing deliberative governance of climate adaptation with traditional policy regimes in different state traditions

\begin{tabular}{ll} 
& Delta Programme ljsselmeer (Netherlands) \\
\hline State tradition & (Neo-)corporatism \\
Institutional & Ad hoc deliberative governance of a \\
arrangements & wide variety of up to 300 \\
& stakeholders coordinated by an ad \\
& hoc administrative office and \\
& steering committee \\
& \\
Players involved & Thirty coordinating civil servants, \\
& four appointed decision-makers \\
& representing all regional political \\
& elected bodies in a DPIJ steering \\
& committee, 300 public and private \\
stakeholders organised in a & network, 100 regional decision- \\
makers organised through \\
'conferences'
\end{tabular}

Process

Problem framing:

A national strategic objective (climate proofing the Netherlands) reframed as a technical task of updating lake Ijsselmeer

Interaction patterns:

Various scale and problem frames existed but the state centred national technical framing remained dominant, yielding cross scale learning but ambiguity about actual implementation and apathy among regional decision-makers and stakeholders struggling with how to make sense of the national technical framing in their own interest

Dependencies:

Ambiguous dependencies due to ad hoc institutionalisation, unclear routines and procedures and abstract nationally scaled technical problem framing
Anglian RFCC's (United Kingdom)

Pluralism

Deliberative governance initiative institutionalised through national acts mainstreaming climate adaptation in local policy partnerships of the EA with local authorities

One independent appointed chair, 6-8 EA expert appointees, and 10 local authority representatives

Problem framing:

After the Pitt Review national government framed water safety as a regional climate change adaptation issue, to be taken care of regionally, with local stakeholder input for decisionmaking and 'partnership' working

Interaction patterns:

Although the reframing did not alter the scale of regional governance structures it did lead to deliberative processes in the committees. This 'partnership' frame to both funding and managing flood controls has to an extent altered local authority roles

\section{Dependencies:}

National legislation leads to relatively clear responsibilities of, and dependencies between organisations involved. This generally leads to negotiation and decision-making in RFCCs
Dry feet 2050 (Netherlands)

(Neo-)corporatism

Institutionalised (neo-) corporatist cooperation of civil servants. 'Priority' stakeholders closely involved through institutionalised deliberation mainstreaming climate adaptation at the administrative level

Twenty Civil servants, five 'priority stakeholders' regularly taking part in project group meetings, four decision-makers. About 40 other stakeholders are bi-annually informed

Problem framing:

Regional flood safety maintenance, reframed as a long term challenge of increasing safety in view of a changing climate

Interaction patterns:

Various scale and problem frames without one dominant framing yielded negotiations over problems, institutional arrangements, strategies and consensus. Social learning remained limited to the limited number of players involved and remained within the institutionalised scope of the project

Dependencies:

Clear dependencies due to institutional setting and explicit frame differences, yielding negotiation and decision-making
Howlett (2009) different state traditions show different policy regimes, which might change over time (Benson et al. 20I3a, 20I3b). This might be illustrated by how the British state tradition, which we labelled pluralism, the water management policy field shows a policy regime akin to the traditional Dutch (neo-)corporatist tradition, where vested interests negotiate with (central) authority. Corresponding the scholarly plea for deliberative governance discussed in 
our introduction, and despite state traditions, the emergence of climate adaptation as a policy issue has sparked deliberative governance initiatives in both British and Dutch water management. These initiatives however, show different institutional arrangements, player involvement and different frames in the deliberative processes.

Deliberative governance dealing with climate adaptation in the Netherlands is unlike the country's (neo-) corporatist tradition of an ad hoc and pluralist character and shows a high degree of puzzling over what is at stake, and only implicit powering strategies over positions in the policy process. The initiative shows institutionally decentred deliberations parallel to constitutional decision-making, yet not routinized or coordinated by national legislation. The large amount of public and private players participating on a voluntary basis with no legal coordination or routines results in processes of learning among a wider array of players but lacks negotiation over explicated frame differences. In that sense deliberative governance initiatives of climate adaptation in the Dutch (neo-)corporatist tradition might be expected to show ambiguous understandings of the climate change issue (Hulme 2009), limited social cohesion and unclear division of responsibility and therefore yields apathy among participants (Pidgeon 2012), or a situation akin to what Darley \& Latane (rg68) have labelled a 'bystander effect' in social psychology (Vink et al. forthcoming).

In line with other cross national studies (Benson et al. 20I3a, 20I3b) pluralism seems only marginally represented in the British flood protection policy regime compared to for example other pluralist state traditions like the US or Australia. Still, different form corporatist Netherlands national government has taken a coordinating role through national legislation to coordinate local agency and to empower nationally set values in regionally formulated policy. This might explain why climate adaptation is less a matter of depoliticized puzzling over possibilities between a wide array of meagrely defined roles and responsibilities like in the Dutch DPIJ case, and more a matter of centralised agenda setting and legally enforced mainstreaming of national values, which leads to regional negotiations with regional authorities at a the regional RFCC level.

Although state traditions do not show a linear relation with policy regimes or deliberative governance processes
(Howlett 2009) and despite limitations of qualitative case study comparisons, our research does suggest that state traditions empirically seem to relate to the institutional arrangements allowing for deliberative governance initiatives. State traditions therefore seem to matter for how deliberative governance initiatives play out. In Dutch corporatism the traditional pattern of negotiation between limited vested interests and (central) government is strong, which might be illustrated by the DV2050 case. The routinized nature of corporatist arrangements with clear role expectations enable a division of tasks to effectively negotiate and decide over complex problems. However, at the same time these patterns lack new entrance of players and ideas and therefore delimit learning. As the case of DPIJ illustrates, the introduction of ad hoc deliberative governance parallels these corporatist flavoured policy regimes, which enables for a wider variety of players and ideas but leads to ambiguous understandings of rules and responsibilities, extensive puzzling and limited action from politically elected decision-makers. This suggests that corporatist state traditions with their institutionalised negotiation patterns do not necessarily enable for ad hoc deliberations as effective decision making arrangements with a wider variety of players.

Even though the traditional water management policy regime in Britain might seem more corporatist than its pluralist state tradition would suggest, deliberative governance initiatives for climate adaptation seem to profit from a state tradition where plurality is traditionally coordinated by the state through legislation. Although player involvement remains limited in the British case, responsibilities and dependencies are clearer due to national legislation coordinating the process. This leads to RFCCs which, unlike the Dutch DPIJ, are the primary decision-making bodies and have to negotiate and decide over (local) priorities in flood protection. Unlike the Dutch DPIJ case national set values are not implicitly empowered through a technical framing like an 'update task', but are explicitly mainstreamed in the local negotiations through national legislation, national funding and EA involvement. Despite methodological limitations of our study, our findings suggest that due to the national focus on legally coordinating regional roles and responsibilities pluralist traditions allow better for deliberative governance initiatives then corporatist 
traditions, which means that in contrast to scholarly pleas deliberative governance should not be viewed as a universal approach to effective climate adaptation. Therefore we position our findings in line with Massey et al. (2014) and Dupuis \& Biesbroek (2013), suggesting that if specific countries are considered best practices for successful climate adaptation initiatives - such as deliberative governance - this should be done with care and not without considering existing practices and country specific traditions in policy style.

\section{CONCLUSION}

Deliberative governance is often proposed to do justice to the cross-cutting challenge of climate adaptation. However, deliberative governance does not necessarily match with existing state traditions in interest intermediations between society and the state (Wilson 1983). To understand how deliberative governance initiatives in the emerging field of climate adaptation play out in different state traditions we conducted comparative case study research. We compared two deliberative governance initiatives for climate adaptation in the water sector in: (1) the Dutch (neo-) corporatist state tradition; and (2) the British pluralist state tradition. To understand the differences between deliberative governance initiatives for climate adaptation with traditional water policy regimes mainstreaming climate adaptation in Dutch water management we conducted a second case study comparison between (1) the Dutch deliberative governance initiative mentioned before and (2) a traditional Dutch water management policy regime mainstreaming climate adaptation as a new challenge.

Our first research questions was: How do framing processes and player involvement of a deliberative climate adaptation governance initiative in the Dutch neo-corporatist state tradition compare to framing processes and player involvement of deliberative climate adaptation governance initiatives in the British pluralist state tradition? First of all, in line with Howlett's (2009) ideas on nonlinearity between state traditions and policy regimes we find that climate adaptation governance in the UK shows less pluralist characteristics as might be expected in a pluralist tradition. Nevertheless, in deliberative governance initiatives dependencies are clearer compared to the Dutch deliberative governance initiatives due to predefined responsibilities and nationally set values explicitly mainstreamed by British national legislation. British deliberative governance initiatives therefore yield framing processes that allow for negotiation and action. In the Dutch deliberative governance initiative a lack of coordination through national legislation yields unclear division of responsibilities. Due to unclear roles and a dominant technical framing set by the coordinating administrators the ad hoc deliberative governance initiative shows less explicit negotiations. Dependencies and responsibilities between national government and the relatively wide variety of regional stakeholders remain ambiguous and regional politically elected decision-makers experience difficulties in negotiating with the national administration. Together with the ambiguous understandings of what the climate issue means, these unclear responsibilities and mutual dependencies result in what can defined as apathy (Pidgeon 2012) or what socio-psychologists have labelled a bystander effect (Darley \& Latane 1968).

Our second research question was: How do framing processes and player involvement in deliberative governance initiatives of climate adaptation compare to the framing processes and player involvement in traditional water management policy regimes taking care of climate adaptation in Dutch neo-corporatism? We find that the deliberative governance initiative in a (neo-)corporatist state tradition yields more extensive puzzling and technical framing among a relatively wide variety of public and private players compared to climate adaptation mainstreamed in typical (neo-)corporatist policy regimes illustrated by the DV 2050 case. Secondly, despite uncertain knowledge and ambiguous understandings associated with climate change impacts on flood management, the typical corporatist policy regime of DV 2050 in the (neo-)corporatist tradition yields relatively clear inter-organisational routines, responsibilities, dependencies, and leads to negotiation frames and subsequent action compared to the DPIJ case. However, because of the clear procedures, preselected 'priority' stakeholders and routines of the typical corporatist policy regime, the approach lacks room for learning (Boezeman et al. 2014).

Despite limitations to qualitative case study comparisons these results suggest that state traditions matter in enabling 
for deliberative governance initiatives. Scholarly pleas for effective climate adaptation through deliberative governance initiatives should be viewed in light of country specific traditions in policy making and interest intermediation.

\section{ACKNOWLEDGEMENTS}

This research has been carried out in the framework of the Dutch National Research Programme Knowledge for Climate (www.knowledgeforclimate.org). This research programme is co-financed by the Ministry of Infrastructure and the Environment.

\section{REFERENCES}

Adger, W. N., Quinn, T., Lorenzoni, I., Murphy, C. \& Sweeney, J. 2013 Changing social contracts in climate-change adaptation. Nat. Clim. Chang. 3, 330-333.

Bache, I. 2000 Government within governance: network steering in Yorkshire and the Humber. Public Adm. 78, 575-592.

Bache, I., George, S. \& Rhodes, R. 1996 The European Union, cohesion policy, and subnational authorities in the United Kingdom. In: Cohesion Policy and European Integration: Building Multi-Level Governance (L. Hooge, ed.). Oxford University Press, Oxford, pp. 294-321.

Barzilai Nahon, K. 2008 Toward a theory of network gatekeeping: a framework for exploring information control. J. Am. Soc. Info. Sci. Technol. 59, 1493-1512.

Benson, D., Jordan, A. \& Smith, L. 2oIza Is environmental management really more collaborative? A comparative analysis of putative 'paradigm shifts' in Europe, Australia and the United States. Environ. Plann. A 45, 1695-1712.

Benson, D., Jordan, A., Cook, H. \& Smith, L. 20Izb Collaborative environmental governance: are watershed partnerships swimming or are they sinking? Land Use Pol. 30, 748-757.

Bevir, M. \& Rhodes, R. 2003 Decentering British governance: from bureaucracy to networks. In: Governance as Social and Political Communication. Institute of Governmental Studies, University of California, Berkely, pp. 61.

Biesbroek, G. R. 2014 Challenging Barriers in the Governance of Climate Change Adaptation. Wageningen University, Wageningen.

Biesbroek, G. R., Swart, R. J., Carter, T. R., Cowan, C., Henrichs, T., Mela, H., Morecroft, M. D. \& Rey, D. 20Io Europe adapts to climate change: Comparing National Adaptation Strategies. Glob. Environ. Change 20, 440-450.

Boezeman, D., Vink, M. \& Leroy, P. 2013 The Dutch Delta Committee as a boundary organisation. Environ. Sci. Pol. 27, 162-171.
Boezeman, D., Vink, M., Leroy, P. \& Halffman, W. 2014 Participation under a spell of instrumentalization? Reflections on action research in an entrenched climate adaptation policy process. Crit. Pol. Stud.

Bourblanc, M., Crabbé, A., Liefferink, D. \& Wiering, M. 2012 The marathon of the hare and the tortoise: implementing the EU Water Framework Directive. J. Environ. Plann. Manage. 56, 1-19.

Boyd, E., Street, R., Gawith, M., Lonsdale, K., Newton, L., Johnstone, K. \& Metcalf, G. 20II Leading the UK adaptation agenda: a landscape of stakeholders and networked organizations for adaptation to climate change. In: Climate Change Adaptation in Developed Nations (J. D. Ford \& L. Berrang-Ford, eds). Springer, New York, pp. 85-102.

Buuren, M. W. v., Klijn, E. H. \& Edelenbos, J. 2012 Democratic legitimacy of new forms of water management in the Netherlands. Int. J. Water Resour. Dev. 28, 629-645.

Cook, H. 1998 The Protection and Conservation of Water Resources: a British Perspective. John Wiley \& Sons, Chichester.

Cook, H. F. 2oIo Boom, slump and intervention: changing agricultural landscapes on Romney Marsh, 1790 to 1990. In: Romney Marsh: Persistence and Change in a Coastal Lowland (M. P. Waller, E. Edwards \& L. Barber, eds). Romney Marsh Research Trust, Sevenoaks, pp. 155-183.

Culpepper, P. D. 2002 Powering, puzzling, and 'pacting': the informational logic of negotiated reforms. Journal of European Public Policy 9, 774-790.

Darley, J. M. \& Latane, B. 1968 Bystander intervention in emergencies: diffusion of responsibility. J. Pers. Soc. Psychol. 8, 377.

Delta Commissie 2008 Working together with water. A living land builds for its future. Findings of the Delta Commissie. Delta Commissie, The Netherlands. www.deltacommissie.com/ doc/deltareport_full. pdf.

Delta Programma 2010 Samenvatting plan van aanpak. Ministerie van Verkeer en Waterstaat, Den Haag.

Delta Programma Ijsselmeergebied 20II Deltaprogramma 2012 Probleemanalyse IJsselmeergebied. Delta Programma IJsselmeergebied, Den Haag.

Dewulf, A. 20I3 Contrasting frames in policy debates on climate change adaptation. Wiley Interdiscip. Rev. Clim. Chang. 4, 321-330.

Dewulf, A., Gray, B., Putnam, L., Lewicki, R., Aarts, N., Bouwen, R. \& Van Woerkum, C. 2009 Disentangling approaches to framing in conflict and negotiation research: a metaparadigmatic perspective. Hum. Relat. 62, 155-193.

Disco, C. 2002 Remaking 'Nature': the ecological turn in Dutch water management. Sci. Technol. Hum. Val. 27, 206-235.

Dolfing, B. \& Snellen, W. 1999 Sustainability of Dutch Water Boards: Appropriate Design Characteristics for SelfGoverning Water Management Organisations. ILRI Special Report No. 9, Wageningen, The Netherlands, 45 pp.

Dovers, S. R. \& Hezri, A. A. 2oro Institutions and policy processes: the means to the ends of adaptation. Wiley Interdiscip. Rev. Clim. Chang. 1, 212-231. 
Dryzek, J. S. 20Io Foundations and Frontiers of Deliberative Governance. Oxford University Press, Oxford.

Dryzek, J. S., Hunold, C., Schlosberg, D., Downes, D. \& Hernes, H. K. 2002 Environmental transformation of the state: the USA, Norway, Germany and the UK. Pol. Stud. 50, 659-682.

Dupuis, J. \& Biesbroek, R. 2013 Comparing apples and oranges: the dependent variable problem in comparing and evaluating climate change adaptation policies. Glob. Environ. Change 23, 1476-1487.

Dyson, K. H. F. I980 The State Tradition in Western Europe: A Study of an Idea and Institution. Oxford University Press, New York.

Environment Agency 2012 Managing Flood and Coastal Erosion Risks: Annual Report by the Anglian (Eastern) Regional Flood and Coastal Committee. Environment Agency, Peterborough.

Feldman, D. L. 2012 The future of environmental networksgovernance and civil society in a global context. Futures $\mathbf{4 4}$, 787-796.

Flyvbjerg, B. 2006 Five misunderstandings about case-study research. Qual. Inq. 12, 219-245.

Gerring, J. 2004 What is a case study and what is it good for? Am. Pol. Sci. Rev. 98, 341-354.

Gov.uk 2013 Flood Risk Management: Information for Flood Risk Management Authorities, Asset Owners and Local Authorities. Defra/UK Government, London.

Halffman, W. 2009 Measuring the stakes: the Dutch planning bureaus. In: Scientific Advice to Policy Making: International Comparison (P. Weingart \& J. Lentsch, eds). Barbara Budrich, Opladen, pp. 41-65.

Hall, P. A. I993 Policy paradigms, social learning, and the state: the case of economic policymaking in Britain. Comp. Polit. 25, 275-296.

Heclo, H. 1974 Modern Social Policy in Britain and Sweden: From Relief to Income Maintenance, Vol. 25. Yale University Press, New Haven.

Hoppe, R. 20II The Governance of Problems: Puzzling, Powering and Participation. The Policy Press, Bristol.

Howlett, M. 2009 Governance modes, policy regimes and operational plans: A multi-level nested model of policy instrument choice and policy design. Pol. Sci. 42, 73-89.

Hulme, M. 2009 Why We Disagree About Climate Change. Cambridge Books, Cambridge.

Ijsselmeergebied, D. P. 20II Plan Van Aanpak Fase 2 en Verder. Delta Programma Ijsselmeergebied, Lelystad.

Kickert, W. J., Klijn, E.-H. \& Koppenjan, J. F. M. 1997 Managing Complex Networks: Strategies for the Public Sector. Sage, Thousand Oaks, CA.

Koningsveld, M. v., Mulder, J. P., Stive, M. J., Van Der Valk, L. \& Van Der Weck, A. 2008 Living with sea-level rise and climate change: a case study of the Netherlands. J. Coast. Res. 24, 367-379.

Koppenjan, J. F. M. \& Klijn, E.-H. 2004 Managing Uncertainties in Networks: a Network Approach to Problem Solving and Decision Making. Psychology Press, Oxford.
Kuks, S. 2002 The Evolution of the National Water Regime in the Netherlands. Euwareness Netherlands. University of Twente, Enschede.

Kuks, S. M. 2009 Institutional evolution of the Dutch water board model. In: Water Policy in the Netherlands: Integrated Management in a Densely Populated Delta (S. Reinhard \& H. Folmer, eds). RFF Press, Washington, USA, pp. 155-170.

Lijphart, A. 2012 Patterns of Democracy: Government Forms and Performance in Thirty-Six Countries. Yale University Press, New Haven, CT.

Manuel-Navarrete, D. 20Io Power, realism, and the ideal of human emancipation in a climate of change. Wiley Interdiscip. Rev. Clim. Chang. 1, 781-785.

Massey, E. \& Huitema, D. 2013 The emergence of climate change adaptation as a policy field: the case of England. Region. Environ. Change 13, 341-352.

Massey, E., Biesbroek, R., Huitema, D. \& Jordan, A. 2014 Climate policy innovation: the adoption and diffusion of adaptation policies across Europe. Glob. Environ. Change

National Audit Office 20II Flood Risk Management in England. The Stationary Office, London.

Nelson, R., Howden, M. \& Smith, M. S. 2008 Using adaptive governance to rethink the way science supports Australian drought policy. Environ. Sci. Pol. 11, 588-601.

Pahl-Wostl, C. 2009 A conceptual framework for analysing adaptive capacity and multi-level learning processes in resource governance regimes. Glob. Environ. Change 19, 354-365.

Pidgeon, N. 2012 Public understanding of, and attitudes to, climate change: UK and international perspectives and policy. Clim. Pol. 12, S85-S106.

Pottier, N., Penning-Rowsell, E., Tunstall, S. \& Hubert, G. 2005 Land use and flood protection: contrasting approaches and outcomes in France and in England and Wales. Appl. Geog. 25, 1-27.

Prak, M. 2008 Polderland. BMGN-Low Countries Historical Rev. 123, 79-87.

Prak, M. \& Luiten van Zanden, J. 2013 De Geschiedenis van Nederland: Nederland en het Poldermodel : SociaalEconomische Geschiedenis van Nederland, 1000-2000. Bakker, Amsterdam.

Purseglove, J. \& Britain, G. 1988 Taming the Flood: A History and Natural History of Rivers and Wetlands. Oxford University Press, Oxford.

Rhodes, R. 2002 The new governance. Public Manage. Crit. Perspect. 44, 208.

Rojas, A., Magzul, L., Marchildon, G. P. \& Reyes, B. 2009 The oldman river dam conflict: adaptation and institutional learning. Prairie Forum 34, 235-260.

Roncoli, C., Kirshen, P., Etkin, D., Sanon, M., Somé, L., Dembélé, Y., Sanfo, B. J., Zoungrana, J. \& Hoogenboom, G. 2009 From management to negotiation: technical and institutional innovations for integrated water resource management in the upper comoé river basin, burkina faso. Environ. Manage. 44, 695-711. 
Sabatier, P. A. 2005 Swimming Upstream: Collaborative Approaches to Watershed Management. MIT Press, Cambridge, MA.

Schmitter, P. C. 1974 Still the century of corporatism? Rev. Pol. 36 , 85-131.

Schön, D. A. \& Rein, M. 1994 Frame Feflection: Toward the Resolution of Intractable Policy Controversies. BasicBooks, New York.

Shackley, S. \& Deanwood, R. 2002 Stakeholder perceptions of climate change impacts at the regional scale: Implications for the effectiveness of regional and local responses. J. Environ. Plann. Manage. 45, 381-402.

Smit, B. \& Wandel, J. 2006 Adaptation, adaptive capacity and vulnerability. Glob. Environ. Change 16, 282-292.

Stuurgroep Droge Voeten 20502011 Startnotitie Project Droge Voeten 2050. Groningen, the Netherlands.

Swart, R. \& Raes, F. 2007 Making integration of adaptation and mitigation work: mainstreaming into sustainable development policies? Clim. Pol. 7, 288-303.

Thomas, G. 20II A typology for the case study in social science following a review of definition, discourse, and structure. Qual. Inq. 17, 511-521.

Tompkins, E. L., Lemos, M. C. \& Boyd, E. 2008 A less disastrous disaster: Managing response to climate-driven hazards in the Cayman Islands and NE Brazil. Glob. Environ. Change 18, 736-745.

Tompkins, E. L., Adger, W. N., Boyd, E., Nicholson-Cole, S., Weatherhead, K. \& Arnell, N. 20Io Observed adaptation to climate change: UK evidence of transition to a well-adapting society. Glob. Environ. Change 20, 627-635. van Buuren, A., Edelenbos, J. \& Warner, J. 20I2 Space for the River: governance challenges andlessons. In: Making Space for the River: Governance Experiences with Multifunctional River Flood Management in the US and Europe (J. F. Warner, A. Van Buuren \& J. Edelenbos, eds). IWA Publishing, London, 187.

Van Buuren, A., Vink, M. \& Warner, J. 20I4 Constructing authoritative answers to a latent crisis? Strategies of puzzling, powering and framing in Dutch climate adaptation practices compared. J. Comp. Pol. Anal. Res. Pract.

van Lieshout, M., Dewulf, A., Aarts, N. \& Termeer, C. 20 II Do scale frames matter? Scale frame mismatches in the decision making process of a 'mega farm' in a small Dutch village. Ecol. Soc. 16, 38.

Vink, M. J. \& Mulligen, E. 2013 Evaluatie Lerend Proces Delta Porgramma IJsselmeergebied. Delta Programma Ijsselmeergebied, Lelystad.

Vink, M. J., Boezeman, D., Dewulf, A. \& Termeer, C. J. A. M. 2orza Changing climate, changing frames: Dutch water policy frame developments in the context of a rise and fall of attention to climate change. Environ. Sci. Pol. 30, 90-101.

Vink, M. J., Dewulf, A. \& Termeer, C. 20I3b The role of knowledge and power in climate change adaptation governance; a systematic literature review. Ecol. Soc. 18.

Vink, M., Dewulf, A. \& Termeer, C. (forthcoming). Unravelling deliberative governance; understanding the interplay between puzzling and powering through frame-interactions.

Visser, J. \& Hemerijck, A. I997 A Dutch Miracle. Amsterdam University Press, Amsterdam.

Wilson, F. L. 1983 Interest groups and politics in Western Europe: the neo-corporatist approach. Comp. Pol. 16, 105-123.

First received 3 March 2014; accepted in revised form 27 September 2014. Available online 23 October 2014 